\title{
Garnaflækja á bugaristli á Landspítala 2000-2013
}

\author{
Hörður Már Kolbeinsson ${ }^{1}$ \\ Birta Dögg Ingudóttir Andrésdóttir ${ }^{1}$ \\ Pétur $\mathrm{H}$. Hannesson ${ }^{2,3}$ \\ Elsa Björk Valsdóttir ${ }^{1,3}$ \\ Páll Helgi Möller ${ }^{1,3}$
}

\section{Höfundarnir eru öll læknar.}

'Skurðlækningadeild Landspítala, ${ }^{2}$ röntgendeild Landspítala, ${ }^{3}$ læknadeild Háskóla Íslands.

Fyrirspurnum svarar Hörður Már Kolbeinsson, hordurma@gmail.com

\section{Inngangur}

Garnaflækja á bugaristli (sigmoid volvulus) er pegar bugaristill snýst um öxul sinn í garnahengjunni (mesentery) með tilheyrandi fráflæðishindrun úr ristli og í sumum tilfellum blóðpurrð og rofi á ristli. Tíðni garnaflækju á bugaristli er lág á Vesturlöndum par sem hún er einungis 3-5\% af öllum garnastíflum (bowel obstruction) á meðan hún er meðal algengustu orsaka garnastíflu í Afríku og Suður-Ameríku. ${ }^{1}$

Meðferð garnaflækju í bugaristli byggir á pví að létta á snúningi ristilsins og koma í veg fyrir frekari köst. Fyrsta meðferð ræðst af ástandi sjúklings við komu á spítala. Ef einkenni á borð við ferska blæðingu um endaparm eða lífhimnubólga eru til staðar verður að hafa í huga blóðpurrð í ristli og/eða rof á ristli sem er ábending fyrir bráðaskurðaðgerð með brottnámi á peim hluta ristils, ýmist með samtengingu eða endastóma (Hartmann procedure). Ef ekki er til staðar ábending fyrir bráðaaðgerð er mælt með að lofttæma paninn ristilinn og vinda ofan af snúningnum í ristilspeglun sem fyrstu meðferð eða mögulega með skuggaefnisinnhellingu með endaparmsröri pó sú meðferð sé á undanhaldi., ${ }^{2,6}$ Pekkt er að endurkoma sjúkdóms geti átt sér stað í allt að 84\% tilvika eftir ristilspeglun og telja pví flestir að líta purfi á ristilspeglun par sem létt er á snúningi ristils sem bráðabirgðameðferð fyrir endanlega meðferð með skurðaðgerð ef sjúklingur er á annað borð fær í aðgerð. $1,5,7,8$ Sumir höfundar hafa lagt til að endanleg meðferð með skurðaðgerð eigi að fara fram sem flýti-valaðgerð (semi-elective) innan tveggja til fimm sólarhringa frá ristilspeglun ef aðstæður leyfa. ${ }^{59}$ Рað skapar rými til að meðhöndla meðfylgjandi sjúkdóma og undirbúa sjúkling frekar fyrir skurðaðgerð. Sú aðgerð sem reynst hefur best er brottnám á bugaristli með samtengingu pó að margar mismunandi leiðir hafi verið reyndar með misjöfnum árangri. ${ }^{2,4,6}$ Meðal pekktra áhættupátta fyrir verri útkomu eftir aðgerð eru lífhimnubólga og drep í ristli.5,10

\begin{abstract}
Á G R I P
Inngangur

Garnaflækja á bugaristli er sjaldgæf orsök garnastíflu í flestum vestrænum löndum. Kjörmeðferð er ristilspeglun og síðar skurðaðgerð. Tilgangur rannsóknarinnar var að kanna meðferð og horfur garnaflækju á bugaristli á Landspítala.
\end{abstract}

\section{Efniviður og aðferðir}

Framkvæmd var afturskyggn rannsókn á einstaklingum sem greindust með garnaflækju á bugaristli á Landspítala á árunum 2000-2013. Farið var yfir sjúkraskrár og skráð kyn, aldur, legutími, meðferð, fylgikvillar meðferðar, vefjagreining og tíðni endurkomu.

\section{Niðurstöður}

Heildarfjöldi sjúklinga var 49; 29 karlar og 20 konur (1,5:1). Meðalaldur var 74 ár (bil: 25-93). Einn sjúklingur fór beint í bráđa aðgerð vegna gruns um lífhimnubólgu, aðrir $(n=48)$ voru meðhöndlaðir með ristilspeglun ( $n=45)$, skuggaefnisinnhellingu um endaparm og endaparmsröri $(n=2)$ eða einungis endaparmsröri $(n=1)$. Prír enduðu í bráđaaðgerð sökum misheppnaðrar ristilspeglunar en 8 sjúklingar fóru í skipulagða aðgerð í legunni. Prjátíu og sex útskrifuðust eftir íhaldssama meðferð með ristilspeglun ( $n=35)$, innhellingu $(n=1)$ eða endaparmsröri $(n=1)$. Tveir sjúklingar lögðust inn síđar til valaðgerðar á ristli. Tuttugu og tveir (61\%) fengu endurkomu sjúkdóms. Miðgildi tíma að endurkomu var 101 dagur (bil: 1-803). Líkur á að fá ekki endurkomu eftir prjá mánuði, 6 mánuði og 24 mánuði voru 66\%, 55\% og 22\%. Heildardánartíðni (innan 30 daga) var 10,2\%. Dánartíðni eftir bráđaaðgerðir var 25\% (1/4) en 16,6\% eftir skipulagðar aðgerðir (3/18).

\section{Ályktanir}

Meirihluti sjúklinga sem ekki fer í ađgerð i fyrstu innlögn fær endurkomu sjúkdóms. Heildardánartíđni vegna garnaflækju á bugaristli á Landspítala er lág en dánartíðni eftir skurðaðgerðir er há.

doi.org/10.17992//bl.2018.09.196

Ekki hafa verið gerðar neinar samantektir á meðferð og horfum sjúklinga með garnaflækju á bugaristli á Landspítala áđur. Markmið pessarar rannsóknar var pví að kanna afdrif sjúklinga með garnaflækju á bugaristli á Landspítala yfir 13 ára tímabil.

\section{Efniviður og aðferðir}

Gerð var afturskyggn rannsókn par sem leitað var eftir ICD-10 greininganúmerinu K 56.2 (garnaflækja). Farið var yfir læknabréf, ristilspeglanir og bráđasjúkraskrár og sjúklingar fundnir sem greindust með garnaflækju á bugaristli á Landspítala á tímabilinu 2000-2013. Greiningin var staðfest með myndgreiningu, 
Tafla I. Sjúkdómsbyrði rannsóknarpýðisins.

\begin{tabular}{lll}
\hline & $\mathrm{n}$ & $\%$ \\
\hline Taugasjúkdómur & 22 & 45 \\
\hline Langvinn hægðatregða & 16 & 33 \\
\hline Gáttatif & 10 & 20 \\
\hline Háprýstingur & 9 & 18 \\
\hline Heilablóðfall & 7 & 14 \\
\hline Hjartabilun & 5 & 10 \\
\hline Geðsjúkdómur & 4 & 8 \\
\hline Blóðpurrðarsjúkdómur í hjarta & 4 & 8 \\
\hline Sykursýki & 4 & 8 \\
\hline Lungnasjúkdómur & 1 & 2 \\
\hline
\end{tabular}

ristilspeglun og aðgerðarlýsingu. Í vafatilfellum voru röntgenmyndir og aðgerðarlýsingar yfirfarnar af sama röntgenlækni og skurðlækni. Skráðar voru upplýsingar um kyn, aldur, legutíma, meðferðarform, dánartíðni, ASA-skor (American Society of Anasthesiologists), vefjagreiningasvar og endurkomur. Dánartíðni var skilgreind sem dauði innan 30 daga frá meðferð.

Ristilspeglun var skilgreind sem heppnuð ef pað tókst að komast fram hjá snúningi ristilsins og létta á prýstingi handan hans auk pess sem einkenni urðu betri og/eða góður árangur var staðfestur á myndgreiningarrannsókn.

Snemmkomin endurkoma garnflækju á bugaristli var skilgreind sem endurkoma sjúkdómsins í sömu sjúkrahúslegu.

Öll gögn voru skráð í Excel 2013 gagnagrunn og notast var við SPSS-tölfræðiforritið við gerð Kaplan Meier-kúrfu. Rannsóknin fékk leyfi Persónuverndar og siðanefndar Landspítala.

\section{Niðurstöður}

Á árunum 2000-2013 fengu 233 sjúklingar á Landspítala greininguna garnaflækja, K56.2. Par af voru 58 sjúklingar með garnaflækju á bugaristli. Voru par af 9 útilokaðir frá rannsókninni, ýmist vegna óljósrar greiningar ( $\mathrm{n}=7)$, aldurs undir 18 ára $(\mathrm{n}=1)$ en einn sjúklingur var erlendur ferðamaður sem ekki var hægt að fylgja eftir. Að lokum voru 49 sjúklingar teknir inn í rannsóknina, par af 29 karlar og 20 konur (1,5:1) og var meðalaldur peirra 74 ár (bil: 25-93). Sjúkdómsbyrði rannsóknarpýðis var töluverð, 22 (45\%) sjúklingar höfðu taugasjúkdóm, meðal annars Alzheimer eða Parkinson-sjúkdóm og 16 (33\%) sjúklingar höfðu pjáðst af langvinnri hægðatregðu. Sjúkdómar á borð við blóðpurrð í hjarta, gáttatif, háprýsting og heilablóðfall voru einnig algengir (tafla I). Algengustu einkenni sem sjúklingar höfðu við komu voru kviðverkir (84\%), pensla á kvið (63\%) og hægðastopp (63\%) en færri höfðu ógleði eða uppköst (14\%). Myndgreining var í flestum tilfellum röntgenyfirlitsmynd af kviði (89\%) en tölvusneiðmynd af kviði var beitt í 19 tilfellum (39\%). Í 11 tilfellum var einungis framkvæmd tölvusneiðmynd af kviði. Skuggaefnisinnhelling í endaparm var framkvæmd í 5 tilfellum í greiningarskyni og í fjórum af peim var skilið eftir endaparmsrör til meðferðar.

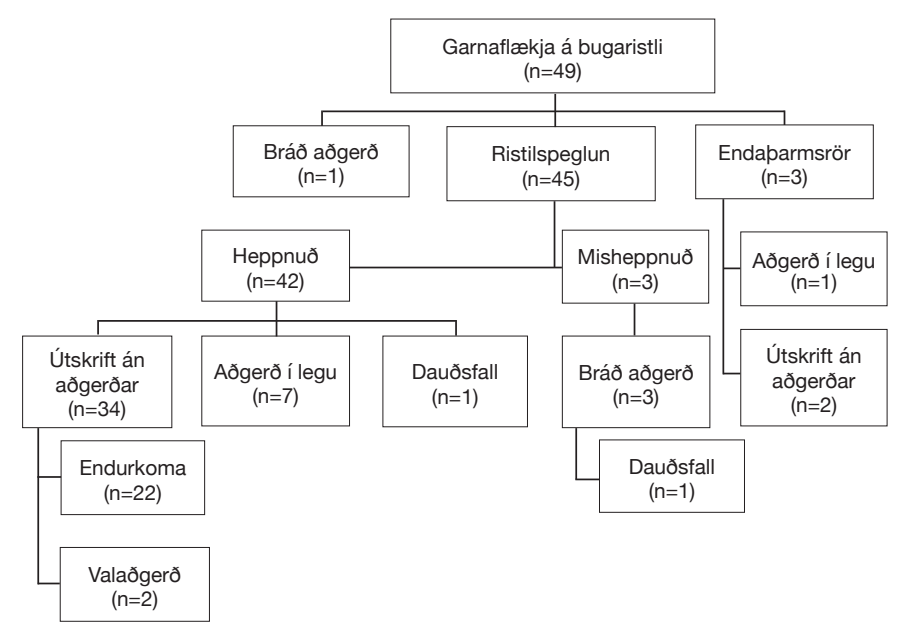

Mynd 1. Flæðirit yfir meðferð sjúklinga í fyrstu innlögn.

Af 49 sjúklingum rannsóknarinnar var einn tekinn til bráðrar aðgerðar vegna gruns um lífhimnubólgu. Hjá öðrum sjúklingum var meðferð fyrst reynd með ristilspeglun $(n=45)$, skuggaefnisinnhellingu um endaparm og endaparmsröri $(n=2)$ eða einungis endaparmsröri í einu tilfelli (mynd 1). Í premur tilfellum tókst ekki að vinda ofan af snúningi og lofttæma ristilinn í speglun og í peim tilvikum voru sjúklingar teknir í bráðaaðgerð. Af peim sem fóru í bráðaaðgerð lést einn skömmu eftir aðgerð sökum aldurs og slæmrar hjartabilunar. Pá fengu prír (6,6\%) sjúklingar snemmkomna endurkomu og purftu aðra speglun daginn eftir. Átta aðrir sjúklingar fóru í flýti-valaðgerð í sömu legu eftir heppnaða ristilspeglun ( $\mathrm{n}=7)$ eða skuggaefnisinnhellingu með endaparmsröri $(n=1)$. ASA-skor var skráð hjá 8 af 12 sjúklingum sem fóru í aðgerð í fyrstu legu og var miðgildið 3 (bil: 2-4). Раð voru 37 sjúklingar sem fóru ekki í aðgerð í legunni og voru flestir peirra $(\mathrm{n}=36)$ útskrifaðir heim. Einn sjúklingur lést í legunni eftir tvær heppnaðar speglanir en sökum aldurs og sjúkdómsbyrði var valið að hefja líknandi meðferð eftir seinni speglunina sem leiddi í ljós sterkan grun um drep í ristli. Skurðaðgerðir voru ýmist brottnám á bugaristli með $(n=6)$ eða án ( $n=6)$ samtengingar.

Af peim 36 sem útskrifuðust án pess að gangast undir skurðaðgerð í fyrstu legu voru 22 (61\%) sem fengu aftur garnaflækju á bugaristli á tímabilinu. Miðgildi tíma að annarri innlögn $(n=22)$ var 101 dagur (bil:1-803). Átta sjúklingar voru teknir til flýti-valaðgerðar í annarri legu og létust prír sjúklingar (37,5\%) í peirri legu, allir í kjölfar aðgerðar. Upplýsingar um ASA-skor var til staðar fyrir 6 af peim 8 sjúklingum sem fóru í aðgerð í seinni legu og var miðgildi pess 3 (bil: 2-3). Dánarorsakir eftir aðgerð voru ásvelgingarlungnabólga skömmu eftir útskrift $(n=1)$, kviðarholssýking í kjölfar leka frá samtengingu ( $\mathrm{n}=1)$ og aldur og fjölkvillar $(\mathrm{n}=1)$. Í seinni legu voru aðgerðir oftast brottnám á bugaristli með samtengingu $(n=7)$ en einn gekkst undir Hartmanns-aðgerð. Tveir sjúklingar komu inn í valaðgerð, brottnám á bugaristli með samtengingu, sem gekk vel. Af peim 36 sem ekki fóru í aðgerð vegna garnaflækju á bugaristli í fyrstu legu voru $66 \%$, 55\% og 22\% sjúk- 


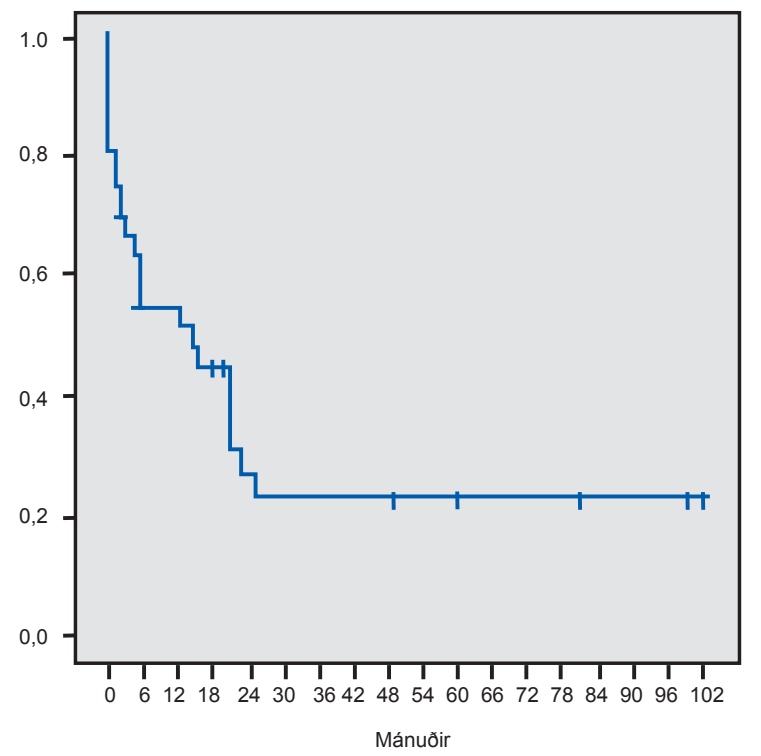

Mynd 2. Sjúkdómsfrílifun.

linga lausir við endurkomu sjúkdómsins eftir prjá, 6 og 24 mánuði (mynd 2).

Heildardánartíðni sökum garnaflækju í bugaristli var 10,2\% (5/49) með 4\% dánartíðni í fyrstu legu en 13,6\% við endurkomu sjúkdóms. Heildardánartíðni eftir skurðaðgerð var 18,2\% (4/22) og skiptist hún í 25\% (1/4) eftir bráðar skurðaðgerðir og 18,8\% (3/16) eftir flýti-valaðgerðir. Enginn lést eftir valaðgerð.

\section{Umræða}

Aldur og kynjahlutfall í okkar rannsókn er sambærilegt pví sem hefur verið lýst í erlendum rannsóknum. ${ }^{3,10}$ Greining fór í flestum tilfellum fram með röntgenyfirlitsmynd af kviði en sjaldnar með tölvusneiðmynd. Er pað í samræmi við pað sem samtök bandarískra ristil- og endaparmsskurðlækna (The American Society of Colon and Rectal Surgeons) mæla með en pau telja pó að hafa purfi lágan pröskuld fyrir tölvusneiðmyndatöku af kviði ef greining er ekki ljós eftir röntgenmynd eða viðbótarmyndir með skuggaefnisinnhellingu. ${ }^{2}$ Einhverjir höfundar mæla með tölvusneiðmyndatöku af kviði sem fyrstu rannsókn sökum yfirburða greiningarhæfni samanborið við hefðbundna röntgenrannsókn og til pess að eiga meiri möguleika á að útiloka æxli á mótum ristils og endaparms sem veldur fráflæðishindrun. ${ }^{5}$

Bráðar aðgerðir vegna gruns um lífhimnubólgu eða merki um rof á görn í myndrannsóknum eru misalgengar í erlendum samantektum, með tíðni á bilinu 5-25\%. Í okkar samantekt gekkst einn sjúklingur (2\%) undir brátt brottnám á ristli vegna gruns um lífhimnubólgu. Eins og áður hefur komið fram er mælt með fyrstu meðferð með ristilspeglun ef ekki er talin pörf á bráðri skurðaðgerð en auk pess að meðhöndla vandamálið tímabundið er ávinningur af pví að meta útlit ristilslímhúðar og sjá pannig fyrir pörfina á valaðgerð innan nokkurra daga. ${ }^{11}$ Í premur tilfellum $(6,6 \%)$ tókst ekki að koma speglunartæki í gegnum snúninginn og lofttæma ristilinn. Pekkt er 5-22\% tíðni misheppnaðra speglana og getur árangur hér pví talist góður. ${ }^{2}$ Í okkar rannsókn fengu prír sjúklingar $(6,6 \%)$ snemmkomna endurkomu garnaflækju eftir ristilspeglun, sem er heldur meira en lýst hefur verið í erlendum rannsóknum (3-
Tafla II. Samanburður á heildardánartíðni eftir skurðaðgerðir við erlendar rannsóknir. 4,6,7,14,15

\begin{tabular}{lc}
\hline Rannsókn & $\%$ \\
\hline Kolbeinsson og félagar 2018 & 18,2 \\
\hline Johansson og félagar 2017 & 7,5 \\
\hline Atamanalp og félagar 2013 & 13,1 \\
\hline Ören og félagar 2007 & 15,8 \\
\hline Labkin og félagar 2009 & 6,6 \\
\hline Bruzzi og félagar 2015 & 0 \\
\hline
\end{tabular}

$5 \%) .{ }^{3}$ Dánartíðni eftir íhaldssama meðferð hefur verið lýst á bilinu 9-36\%, sem er heldur hærra en í okkar samantekt par sem einn sjúklingur af 37 (2,7\%) sem ekki fóru í aðgerð lést í fyrstu legu. ${ }^{5}$

Mismunandi skurðaðgerðir hafa verið reyndar til að meðhöndla garnaflækju í bugaristli. Hingað til hefur engin peirra sýnt sama árangur og brottnám á bugaristli, ýmist með samtengingu eða ristilstóma og er pað sú aðgerð sem gerð var í öllum tilfellum á Landspítala. ${ }^{2,6}$ Einhverjir höfundar hafa lagt til að rétt sé að íhuga ristilstóma á bugaristli í ristilspeglun (percutaneous endoscopic colostomy) pegar sjúklingar eru ekki taldir hæfir í skurðaðgerð en sú aðferð er enn til skoðunar hjá pessum sjúklingahópi og árangur virðist góður.12-14 Dánartíðni eftir valkvæðar skurðaðgerðir var $18,1 \%$ (3/18) og enn hærri eftir bráðar aðgerðir, eða 25\% (1/4), en petta verða að teljast háar tölur í erlendum samanburði par sem dánartíðni eftir skurðaðgerðir hefur verið lýst á bilinu 0-12\% í kjölfar heppnaðrar ristilspeglunar og allt að 20\% ef um bráðaðgerð er að ræða. ${ }^{2,4}$

Ljóst er að peir sjúklingar sem ekki fara í aðgerð eru í töluverðri hættu á að fá endurkomu sjúkdóms og eru uppi vísbendingar um að líkur á endurkomu aukist eftir pví sem frá líður.,8,15 Okkar niðurstöður sýna heildarendurkomutíðni 61\% (22/36) og er pað svipað erlendum tölum sem yfirleitt eru í kringum $60 \%$ en ná hæst upp í 84\%. ${ }^{7,8,15,16}$ Mynd 2 sýnir líkur á sjúkdómsfrírri lifun í mánuðum en par kemur fram að líkur á priggja, 6 og 24 mánaða lifun án endurkomu var $66 \%$, 55\% og 22\%. Petta eru ekki ósvipaðar tölur og í grein frá 2014 par sem fram kemur að 63\%, 47\% og 24\% líkur voru á að sleppa við endurkomu sjúkdóms premur, 6 og 24 mánuðum eftir fyrstu útskrift án aðgerðar. ${ }^{8}$

Garnaflækja á bugaristli er hættulegur sjúkdómur en dánartíðni sökum sjúkdómsins hefur verið lýst milli 8-28\% í erlendum samantektum. ${ }^{11}$ Heildardánartíoni á Landspítala reyndist vera 10,2\%, í fyrstu innlögn 4\% en 13,6\% hjá peim sem purftu endurtekna innlögn. Í einu tilfelli var ekki reynd skurðaðgerð sökum aldurs og sjúkdómsbyrði og er pað ekki óvanalegt pegar pessi sjúklingahópur er annars vegar. Pær alpjóðlegu leiðbeiningar sem til eru leggja áherslu á að hvert tilfelli sé metið fyrir sig. ${ }^{2}$ Að sama skapi er mikilvægt að hafa í huga að endurkoma sjúkdómsins ber með sér mikla hættu á dauða og fylgikvillum og ef kostur er pá eigi að framkvæma hálf-brátt brottnám á bugaristli með samtengingu. 2,8,11 Tiltölulega hátt dánarhlutfall eftir skurðaðgerðir í okkar samantekt er erfitt að útskýra öðruvísi en að sjúklingar rannsóknarinnar eru oft aldraðir og með sjúkdóma sem auka áhættu við aðgerð. Tafla II sýnir samanburð á heildardánartíðni eftir skurðaðgerð vegna garnaflækju á bugaristli við nokkrar erlendar rannsóknir. Mikill munur er á dánartíðni eftir bráðar 
skurðaðgerðir milli rannsókna en pví hefur verið lýst á bilinu 10$100 \%$ pó að oftar en ekki sé tíðnin í kringum 10\%.1,4,15 Hjá okkur var 16,6\% dánartíðni eftir skipulagðar aðgerðir, sem er hærra en yfirleitt er lýst erlendis og teljum við pað styrkja pá skýringu að aldur og almennt ástand pessara sjúklinga spili hér stórt hlutverk. Petta dánarhlutfall virðist töluvert hærra en við aðgerðir á ristli og endaparmi í flestum öðrum sjúklingapýðum, til dæmis vegna krabbameins en í nýlegri íslenskri samantekt var 30 daga dánartíðni eftir aðgerð undir $1 \%{ }^{17}$

Helsti annmarki pessarar rannsóknar er að hún er afturskyggn og reiðir sig pví á nákvæma skráningu upplýsinga í sjúkraskrárkerfi, sem getur verið ábótavant.
Með pessari samantekt var leitast við að varpa ljósi á afdrif sjúklinga með garnaflækju á bugaristli á Landspítala. Ljóst er að garnaflækja á bugaristli er hættulegur sjúkdómur sem hefur sterka tilhneigingu til endurkomu. Sjúklingar eru oft á tíðum aldraðir og pjást af sjúkdómum sem gera ákvarðanatöku um meðferð erfiða. Endurkomutíðni hér er há eins og pekkt er. Heildardánartíðni á Landspítala vegna garnaflækju á bugaristli er lág í erlendum samanburði en virðist aukast við endurteknar innlagnir og er há eftir skurðaðgerðir.

\section{Heimildir}

1. Raveenthiran V, Madiba TE, Atamanalp SS, De U. Volvulus of the sigmoid colon. Colorectal Dis 2010; 12 e1-17.

2. Vogel JD, Feingold DL, Stewart DB, Turner JS, Boutros $\mathrm{M}$, Chun J, et al. Clinical practice guidelines for colon volvulus and acute colonic pseudo-obstruction. Dis Colon volvulus and acute colonic
Rectum 2016; 59: 589-600.

3. Atamanalp SS. Sigmoid volvulus: Diagnosis in 938 patients over 45.5 years. Tech Coloproctol 2013; 17: 419-24.

4. Atamanalp SS. Treatment of sigmoid volvulus: a singlecenter experience of 952 patients over 46.5 years. Tech Coloproctol 2013; 17: 561-9.

5. Perrot L, Fohlen A, Alves A, Lubrano J. Management of the colonic volvulus in 2016. J Visc Surg 2016; 153: 183-92.

6. Ören D, Atamanalp SS, Aydinli B, Yildirgan MI, Başoğlu M, Polat KY, et al. An algorithm for the management of sigmoid colon volvulus and the safety of primary resection: Experience with 827 cases. Dis Colon Rectum 2007; 50: 489-97.
7. Johansson N, Rosemar A, Angenete E. Risk of recurrence of sigmoid volvulus: a single-center cohort study. Colorectal Dis 2018; 20: 529-35.

8. Ifversen AKW, Kjaer DW. More patients should undergo surgery after sigmoid volvulus. World J Gastroenterol 2014; 20: 18384-9.

9. Tsai M-S, Lin M-T, Chang K-J, Wang S-M, Lee P-H. Optimal interval from decompression to semi-elective operation in sigmoid volvulus. Hepatogastroenterology 2006; 53: 354-6.

10. Halabi WJ, Jafari MD, Kang CY, Nguyen VQ, Carmichael JC, Mills S, et al. Colonic volvulus in the United States: trends, outcomes, and predictors of mortality. Ann Surg 2014; 259: 293-301.

11. Atamanalp SS, Atamanalp RS. The role of sigmoidoscopy in the diagnosis and treatment of sigmoid volvulus. Pakistan J Med Sci 2016; 32: 244-8.

12. Tun G, Bullas D, Bannaga A, Said EM. Percutaneous endoscopic colostomy: A useful technique when surgery is not an option. Ann Gastroenterol 2016; 29: 477-80.
13. Frank L, Moran A, Beaton C. Use of percutaneous endoscopic colostomy (PEC) to treat sigmoid volvulus: a systematic review. Endosc Int Open 2016; 4: E737-E741.

14. Bruzzi M, Lefèvre JH, Desaint B, Nion-Larmurier I, Bennis M, Chafai N, et al. Management of acute sigmoid volvulus: Short- and long-term results. Color Dis 2015; 17: volvul $922-8$.

15. Labkin JO, Thekiso TB, Waldron R, Barby K, Eustace PW Recurrent sigmoid volvulus - Early resection may obviate later emergency surgery and reduce morbidity and mortality. Ann R Coll Surg Engl 2009; 91: 205-9.

16. Yassaie $\mathrm{O}$, Thompson-Fawcett M, Rossaak J. Management of sigmoid volvulus: Is early surgery justifiable? ANZ J Surg 2013; 83: 74-8.

17. Kolbeinsson HM, Valsdóttir EB, Möller PH. Árangur brottnáms á endaparmi vegna krabbameins eða forstiga pess á Landspítala 2008-2012. Læknablaðið 2017; 103: 5315 .

Barst til blaðsins 13. mars 2018, sampykkt til birtingar 29. júní 2018.

\section{ENGLISH SUMMARY}

\section{Sigmoid volvulus at the University Hospital of Iceland 2000-2013}

\author{
Hörður Már Kolbeinsson' \\ Birta Dögg Ingudóttir Andrésdóttir ${ }^{1}$ \\ Pétur H. Hannesson ${ }^{2,23}$ \\ Elsa Björk Valsdóttir ${ }^{1,3}$ \\ Páll Helgi Möller ${ }^{1,3}$
}

\section{Backround}

Sigmoid volvulus is an uncommon cause of bowel obstruction in most western societies. Treatment options include colonoscopy in uncomplicated disease with elective surgery later on. The aim of this study was to assess what treatment sigmoid volvulus patients receive along with long-term outcomes at Landspitali University Hospital.

\begin{abstract}
Methods
The study was retrospective. Patients diagnosed with sigmoid volvulus at Landspitali University Hospital from 2000-2013 were included. Information regarding age, sex, and duration of hospital stay, treatment, short and long-term outcomes were gathered.
\end{abstract}

\section{Results}

Forty-nine patients were included in the study, of which 29 men and 20 women. Mean age was 74 (25-93). One patient underwent acute surgery on first arrival due to signs of peritonitis. Others $(n=48)$ were treated conservatively in the first attempt with colonoscopy $(n=45)$, barium enema $(n=2)$ and rectal tube $(n=1)$. Three other patients underwent acute surgery due to failed colonoscopy, 8 patients had planned surgery during the index admission. Thirty-six patients were discharged after conservative treatment with colonoscopy $(n=35)$, barium enema $(n=1)$ or rectal tube $(n=1)$. Two patients came in for elective surgery later on. Twenty-two patients (61\%) had recurrence. Median time to recurrence was 101 days (1-803). Disease-free probability in 3, 6 and 24 months was $66 \%, 55 \%$ and $22 \%$ respectively. Total disease related mortality was $10.2 \%$. Mortality (30 days) after acute surgery was $25 \%$ $(1 / 4)$ and $16,6 \%(3 / 18)$ after planned surgery.

\section{Conclusions}

Sigmoid volvulus has high recurrence rate if not treated operatively. Total mortality due to sigmoid volvulus at Landspitali is low but surgery related mortality high. 